Article

\title{
Configuring a Trust-based Inter-organizational Cooperation Network for Post-industrial Tourist Organizations on a Tourist Route
}

\author{
Mateusz Naramski * (D) and Adam R. Szromek \\ Department of Organization and Management, Institute of Economy and Informatics, \\ Silesian University of Technology, Akademicka 2A, 44-100 Gliwice, Poland \\ * Correspondence: Mateusz.Naramski@polsl.pl; Tel.: +48-32-277-73-36
}

Received: 20 May 2019; Accepted: 25 June 2019; Published: 27 June 2019

check for updates

\begin{abstract}
The aim of the paper was to create a configuration model of an inter-organizational network for post-industrial tourist organizations. Nowadays, establishing organized and structured cooperation is necessary not only from a single organization's perspective, which fights for survival on a highly competitive market, but also from the perspective of a whole touristic region. The quality and social responsibility of a regional touristic product is determined not by a single organization, but by their collective outcome. The main goal was achieved by the analysis of tourist sites, their function within the Industrial Monuments Route (IMR) in Poland, as a case for the conducted study. The authors used trust level indicators as determinants for designating inter-organizational relations in the wrought network model. Those relations concern various forms of cooperation that the researched organizations have selected during a structured interview and were willing to undertake under given conditions. The result is a multi-dimensional model of a cooperation network that can be implemented at IMR and used as a guideline for creating similar models for other thematic tourist routes.
\end{abstract}

Keywords: cooperation; inter-organizational networks; tourist routes

\section{Introduction}

Tourist routes are facing the necessity of continued development and improving their offer to meet the ever increasing expectations of tourists. Escalating competition results in a situation, when today's tourist can select the consumer product or service from the offer of many producers, having access to a broad range of alternatives at the same time. Therefore, nowadays, independent activity of tourist entities on the market occurs only in isolated cases. Inter-organizational networks are a developed form of cooperation. It may be stated that a network is one of the possible further steps in the evolution of cooperation, after bilateral cooperation or cooperation directed in a top-down manner. The advantage of networking is the possibility to control the process of its creation and plan its structure [1]. Here, the findings of K. Czernek and M. Żemła [2] must be brought up, that despite the justified usefulness of networks in tourism - their self-formation very rarely allows to achieve an optimum form of cooperation and network configuration; this process must therefore be planned, organized and controlled in order to achieve an efficiently functioning network. Therefore the aim of this paper is to develop and apply a method of inter-organizational network planning and configuration on a tourist route. Our intention is also for this method to be adequate for routes where there was no previous horizontal interaction between potential partners, and all the activates carried out have been imposed by a unit that governs the route (in other words managed only in bottom-top manner) - as it is in the selected case for the empirical research. This is the reason why the 
developed method will designate network connections between tourist sites within a route, basing on their level of inter-organizational trust. Trust is a known factor that influences cooperation and was researched in this scope since the past century [3]. From the social perspective, applied i.a. by F. Fukuyama [4], it is beneficial to perceive cooperation as a result of trust between organisations, given the mutual reinforcement of social trust and social networks [5]. Trust can be measured within a route, even if there were no significant holding activities in the past, just in the scope of sites being members of the same construct. Therefore the method should allow one to design the initial concept of an inter-organisational network, focusing on its internal configuration, before accommodating for external factors and appliance of already known methods for network optimisation when the network cooperation is established.

The creation of tourist routes and their development, including the development of more and more complex forms of cooperation by the sites forming this route, provides not only economic benefits, but also constitutes a source of added value for the local communities [6,7]. The tourism of post-industrial sites and routes they form is an important element in the sustainable development of the region [8]. On the one hand, it allows to preserve the tangible and intangible heritage through commercialization, thus providing the funds necessary for its maintaining and lifting the burden off of self-government authorities in this respect $[9,10]$, and on the other hand, it creates an opportunity for local communities to conduct gainful activity, based on knowledge and culture, which - without tourism - would have been forgotten and not passed down to the next generations. However, it must be emphasized that tourist activity may provide adverse effects in an unsustainable manner, degrading the heritage and the natural environment [11]. The literature on the subject provides examples of how the knowledge of the inter-organizational network structure contributed to identifying the impact of the organizations belonging to the network on sustainable development, in terms of the environment, energy, public safety, energy economy etc. [12-15]. Therefore, an arbitrarily planned network of cooperation for entities operating on the tourist route may - in the future - facilitate the identification of channels of flow of information, knowledge, raw materials and tourist traffic on the route and, at the same time, maintain its impact on the environment and plan its development in a sustainable and socially responsible manner.

\section{Inter-organizational Networks}

One of the contemporary definitions of a network, formulated in 1999 by C.M. Hall [16], defines it as an inter-organizational agreement on cooperation. The advantages of using it include increased efficiency, quality and end value offered to the client. However, a decade later, the same author [17] noted, that using strictly defined economic and business solutions cannot be effectively applied to a sector as complex as tourism. In the subsequent years, this issue was studied again and network management became an alternative to conventional management in public sectors.

The so-called network actors assume one of the three roles [18]:

- $\quad \operatorname{architect~(forms~the~initial~network~and~is~the~creator~of~mechanisms~responsible~for~their~durability,~}$ defines the principles of cooperation and determines the roles of individual network members),

- mediator (plays the role of an arbiter in situations of conflict and controversy),

- $\quad$ broker (is the coordinator of undertakings).

Relations in networks often consist in cooperation agreements, but not every actor must be directly connected with other members of the network; instead, intermediary connections are established [19]. This phenomenon is one of the factors attributing numerous distinguishing features to networks, including [20]:

- making decisions on resources partially takes place in a collective manner, and not merely in an integral form, at the level of the parent companies,

- resources flow between the participants of the network in a repeatable manner, instead of on an ad-hoc basis, 
- cooperation and partnership are established on a long-term basis,

- there is an increase in freedom of exchange of information between allies,

- competition is replaced with negotiations and agreements in the field of coordination of actions of the network members,

- part of the tasks, previously performed by one organization, is replaced with a group of tasks performed by numerous organizations within the network,

- control and planning activities are minimized,

- network structure is flexible - it allows for easy changes in the configuration of the network arrangement.

Reliable coordination of cooperation has material importance for effective cooperation [21], understood as the ability to achieve the assumed goals [22]. Additionally, cooperation may bring manifold benefits to the entities operating within a network structure; however, to achieve them, it is necessary to meet certain conditions. It may be therefore assumed, that the network should function on the basis of the adopted mechanisms, which include certain mechanisms of coordination [22-24]:

- market coordination (managing potential conflicts and expectations of partners, as well as division of specialties, competencies and expectations with regard to the quality of the produced goods and services within the network),

- hierarchical coordination (defining rules, procedures and norms of cooperation, as well as describing the principles and guidelines for flexible control of the whole network),

- social coordination (based on quick, effective and conflict-free communication, as well as high degree of mutual trust among the network participants).

The mechanisms of the first group are mostly dependent on the managerial and leadership abilities of persons managing the sites within the network. The division of competences should be reflected in the structure of the network. It is this structure that, to a large extent, determines the second type of mechanisms of coordination. In the view of the presented information, it may be concluded that, while designing the network, the respective division of roles and hierarchies within the network has high importance for its functioning. However, for the other participants in the network to recognize the leader roles in the network, it is necessary to awaken trust, without which full cooperation would not be possible.

Inter-organizational networks can be a subject to social network analysis. By visualizing its structure one is able to recognize connection patterns [25], as well as by analyzing the nodes and ties parameters the problem areas of a network can be identified (i.e., a too high or a to low level of centralization, too long paths, a too high level of asymmetry, etc.) [26]. The social network analysis can be also used to identify relations between network members or between members behavior and structural patterns. This approach is useful in various types of networks, from commercial cooperation between businesses, through public institutions, till resources management like i.e., water [27] or food [28]. Research also [29] indicates that network nodes should be described from the perspective of relations between the actors.

When cooperation between multiple entities begins it usually emerges from a vertical governance model [30]. As the cooperation develops more and more efforts are carried out at the organizational level and hierarchical order falls in favor of self-organization [31,32].

Even if cooperation is the main goal of an inter-organizational network there's always a certain degree of competition between its members. Research results show that sometimes networks consist of entities that are active competitors, nevertheless they enter cooperation to achieve common goals [33]. Therefore in order to comprehend networks one has to realize, that relations inside a network can have various nature, on one side of the spectrum there are cooperative relations based on mutual trust, on the other one - competitive ones, where distrust dominates [33-35]. Every member of a network peruses the common goals of a network, but at the same time they also want to achieve own 
organizational goals and not be completely dependable on their partners. Trust plays a major role in maintaining a balance between those opposing demands, by promising equivalence [36]. Thus, trust can be considered an essential element of every network [37], because it helps to achieve its goals and performance [38,39]. However some researches claim that distrust can also bring positive effects, as well as trust can lead do negative ones [40]. The argument is that too much trust can lead to a too high dependence on partners and can be abused [33]. On the other hand lack of trust is considered by some researches [41] as a threat for network stability, other factors named by them: high complexity and difficulty levels of processes realized with partners, too much dependence on partners, and different level of development in knowledge and skill absorption.

\section{Cooperation in Networks and in Tourism}

In the conditions when there is fierce competition on the market, high level of specialization of enterprises and quick development of technologies, it becomes necessary to operate flexibly and reduce costs, causing the independent operation of an enterprise to be almost unattainable [42]. Cooperation networks are forms that allow the establishment of initial cooperation and its subsequent development. Cooperation has three distinguishing features that may differentiate it from other forms of collaboration [43]:

- cooperating entities preserve their legal personality,

- each entity preserves its decision-making autonomy,

- cooperation is entirely voluntary and reversible.

The network approach to management proves to be a useful solution in many areas (e.g., in sociology, economy, geography and political science); with the outbreak of the new millennium, it started gaining higher and higher popularity in managing tourism [44]. The network approach continues to be developed and applied also to tourist routes, since it allows to account for the relationship between the tourist product of the region and the space of local communities, which give significance to the routes. The first breaking point took place in the 1990s. It was then, when the network approach gained acceptance in tourism management, responding to the growing need of co-ordination, independent from markets and hierarchies [32]. Three milestones can be distinguished in the process of adapting the network approach to tourism. The first was the emergence of a need to apply a more managerial perspective in managing the tourism area, which would replace management through the public sector $[16,45]$. In this approach, the managerial role is played by local private stakeholders, and the role of self-governments is limited to coordinating economic and social agents; they should play the role of active brokers for the network [44]. Another milestone was to formulate the benefits that could be expected by tourist enterprises by participating in the network. Mentioned here were: an increase in inter-organizational learning and sharing knowledge, which - in consequence - is supposed to lead to increased competitive advantage, since cooperation reduces costs and contributes to creating added value to the client [46-49]. The third important postulate is to understand that a tourist product is perceived by the client holistically; hence, it is necessary to integrate and coordinate, and therefore the management of tourist area must be broader than a unitary perspective [50,51].

Significant part of the contemporary research was devoted to discovering the potential of the paradigm of network for the management and development of tourism [52-54]. Research shows that the tourist sector requires a network approach, since it allows organizations and tourist areas to function in the changing, complex and competitive environment [53,54]. Many authors also claim that the network perspective may be used by the stakeholders to increase innovativeness, competitiveness, level of knowledge sharing and stimulating sustainable development $[55,56]$. However, in the literature of the subject there is lack of consistency as to the approach and methodology that should be used in studying tourist networks [52,57], and the measurement and assessment of cooperation effectiveness is an issue with no ambiguous solution [30]. 
For instance, the Industrial Monuments Route (a tourist route that consist of 42 industrial tourism sites in southern Poland) shows that, in case of tourist routes, there is no homogeneity in terms of form of ownership. This applies not only to industrial routes, but the majority of cultural routes created by entities belonging to the private, public and non-governmental sector. In this case, the network will exhibit traits of a cooperation network, but it should also be considered from the perspective of public-law networks.

Public-law networks have the following features [42]:

- they are created by entities independent of each other, where at least one of them is subject to public law,

- the purpose is joint implementation of public interest (attaining profit by private entities is also possible),

- processes of learning occur, consisting in mutual matching of the network participants to each other,

- participants are independent entities, joining the networks on their own,

- $\quad$ relational rent proves the ability to implement tasks of public nature.

In managing tourist networks, three basic coordination models can be seen [58]: a network operated by a self-government authority (council, office etc.), a network operated by its members (self-coordinating) and a network operated by a local tourist organization. Regardless of the assumed form, proper coordination depends primarily on the actors of the network and the groups related to them, their aspirations and beliefs, as well as the decisions made in terms of responsibility, transparency, participation, communication, sharing knowledge, efficiency and justice [58]. The efficiency of coordination of local tourist networks in achieving goals depends on the effectiveness of institutional processes and structures, relational resources and available skills [59-61]. Institutional structure is, in other words, the formal and informal substructure that creates organizations, their autonomy, authority, internal cohesion and discipline in organization [58]. The study of D. Dredge [62], in which the theoretical approach to applying networks in tourism was analysed, shows that the network approach for tourism is characterized by four main advantages:

- networks take into account the divergence in solving problems in tourism, which often appear simultaneously and overlap, and which are solved by different communities that represent different approaches in their scale and time frame,

- the network approach accounts for the blurred division between the private and public sectors, and allows to perceive tourism as a multi-dimensional space that properly fits into the principles of common interest of these two groups,

- networks allow for the occurrence of different levels of political support for different problems, therefore the degree of attention devoted to the individual problems may vary significantly,

- the network approach recognizes that the stakeholders of a given network may be participants of other networks, and therefore their impact, role, interactions undertaken and their function in the network change respectively.

J. Kurowska-Pysz and K. Szczepańska-Woszczyna [63] researched the case of cross-border cooperation between Poland and Czech Republic, where tourism was one of the most highly recognized areas of coss-border inter-organizational areas of cooperation. Although in this case the cooperation relies more on bilateral partnerships than networks, this structure is suggested to be taken into consideration if there should be decided that there is a need for a more advanced cooperation model. However, their research findings contain conditions that had to be met in order sustain a good partnership, those are [63]:

- $\quad$ similar and compatible interests and expectations,

- awareness of benefits and needs expected from cooperation,

- willingness to share the benefits as well as the costs and risks of cooperation, 
- possession of proper resources needed to cooperate,

- honest motivation to participate in cooperation,

- concentration on long-term relation.

Additionally those findings are supplemented by 3 principles that provide good cooperation conditions [63]:

1. The partnership is based on equal rights, that lead to mutual respect;

2. The relationships is transparent, so trust can develop;

3. The benefits are mutual for all partners, so the cooperation stays stable.

The importance of inter-organizational networks is a known issue [64]. The expected outcome is knowledge sharing and transfer, consequently increasing competitiveness and innovation in network connected sites. The study by Presenza and Cipollina [64] that was dedicated the analysis of truism stakeholders network empathizes on this, and in their conclusions the researchers underline, that trust should be considered as a necessary dimension in building, sustaining and developing cooperation in tourism.

As we have shown, literature of the subject focuses either on explaining the paradigm of networks, their expected outcome and conditions that have to be met in order for cooperation to be effective or on analyzing existing networks; measuring their effectiveness, performing social network analysis and finding fields that can be potentially improved. In tourism, the network approach is either applied in context of whole tourism regions, or for whole industries (i.e., hospitality). But we found no evidence of inter-organizational network approach application in case of a tourist route, all the more an attempt to actually design a network structure for tourist sites that form a route. Our study contributes to explore this issue.

In view of the presented information, it may be concluded that, when configuring a new network for industrial tourist sites, taking into consideration the forms of ownership and model of management in the individual sites is very significant. The reason is the endeavour to reduce the level of engagement between public stakeholders plus local communities and the entrepreneurs. It is also important to create new affiliations of horizontal nature between the participants of the network, that will be based on a broadly understood proximity. Another important aspect is determining network nodes, bringing together weaker units, that may provide example and support for smaller organizations, as well as brokers of the network for coordinating its activities. A properly configured network should bring benefits to all its participants due to the effect of synergy. The network is capable of allowing the more effective control of tourist traffic and accelerating the process of creating new knowledge, improving its quality and effectiveness, with which it is spread within the network and utilized. Achieving this effectiveness largely depends on the level of communication and engagement, and these, in turn, are the effect of trust between the potential network actors.

\section{Materials and Methods}

The empirical research was conducted in 2017 in the course of 6 months in all 42 entities functioning within the Industrial Monuments Route (IMR) that is located in Southern Poland. Historically this was the region where the industrial revolution began within the borders of nowadays Poland. Southern Poland is the main coal basin, that was industrialized already at the end of $18^{\text {th }}$ century during the Prussian Partition. Therefore this is the region with the oldest, most developed and best preserved industrial heritage in country. IMR is also the only tourist route in Central Europe that is a member of the European Route of Industrial Heritage (ERIH). Other industrial routes in Poland are much smaller (in terms of number of sites - each of them counts less than half of IMR sites) and are also not as diverse (focusing only on one type of facilities, like railway, lighthouses, wooden constructions), while IMR includes different types of facilities (mines, museums, breweries, settlements etc.). Additionally, the high level of formalization and development of IMR argue in favour of choosing it as a case for this 
study. Therefore the findings from a research that pertains to IMR should be applicable to other ERIH routes or serve a raw model for less developed routes, that are in pursuit for this international standard.

The configuration of inter-organizational network based on cooperation, presented in the paper, was created with sites situated along the Industrial Monuments Route in mind, but it seems that this limitation is merely symbolic, as similar behaviors are observed on other thematic routes.

IMR was established in 2004 by Marshal's Office of the Silesian Voivodeship, which has managed the route since its creation, up to this day. IMR is a thematic car route that covers the monuments of industry within the entire voivodeship. At the time of the conducted studies, the route included 42 sites located in 27 towns and cities. The map and list of IMR sites is presented in Figure 1.

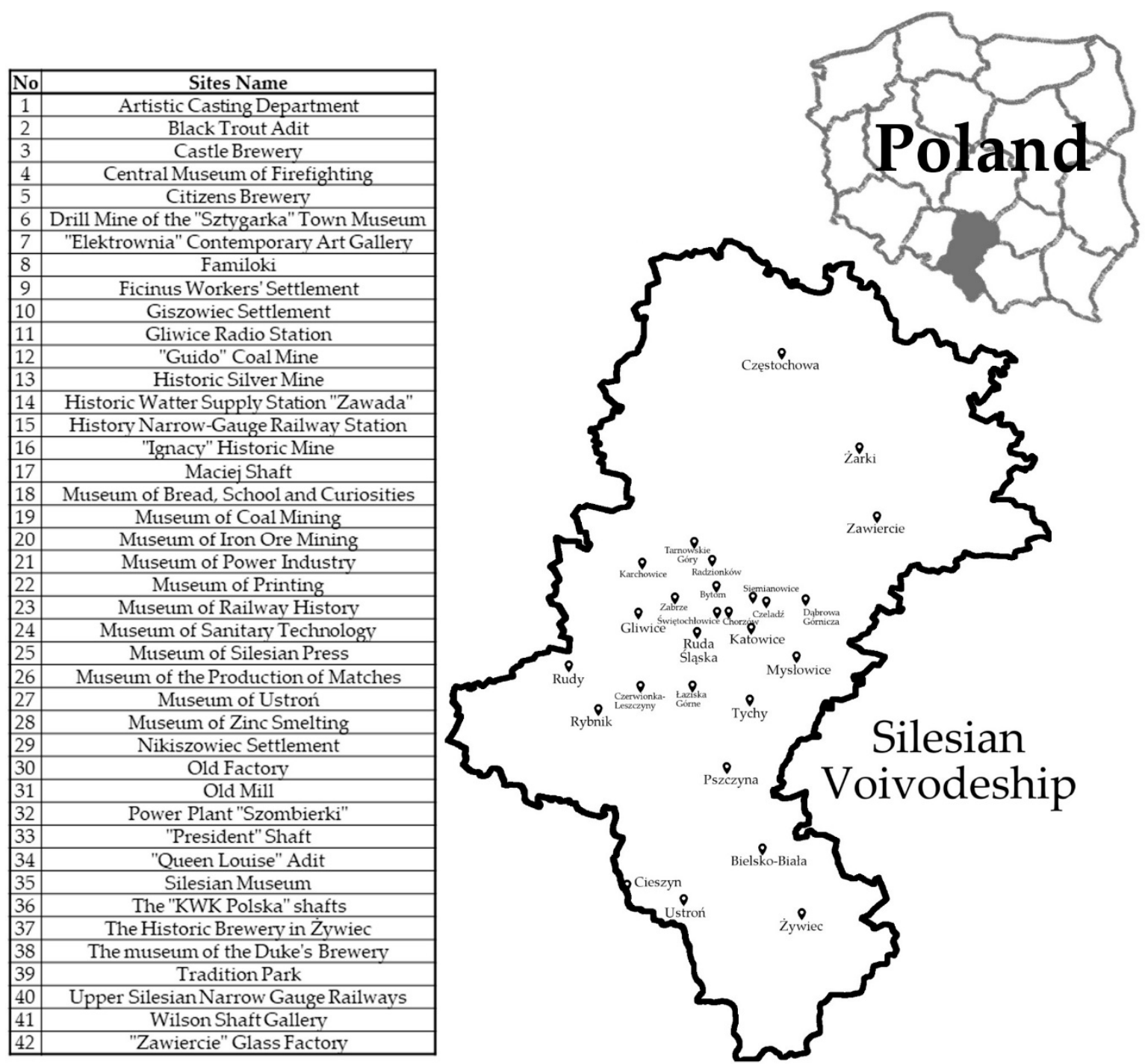

Figure 1. IMR sites on the map of the Silesian Voivodeship. Source: Authors own work.

Along with the growth of popularity of the post-industrial tourism in the region and the development of the route, the managers have continuously improved its form and are seeking for solutions capable of increasing the effectiveness of cooperation between the route sites. The model of an inter-organizational network, based on inter-organizational trust, designed with cooperation of post-industrial tourism entities in mind, is a tool that can bring the IMR managers closer to achieving this goal.

The main study was divided into two phases. In the first phase [65] structured expert interviews with managers of all IMR sites were conducted. During the interviews an overall characteristic of each 
site was made (theme of the site, available attractions and services, years of functioning, legal form of organisation, number of employees, the dimension of tourist traffic). Then each subject was asked to assess the trust level and communication efficiency with 9 other sites ( 3 of them were the nearest, 3 the furthest, and 3 most similar institutionally). The data was also supplemented with attitudes in each given site towards the process of networking and cooperation development within IMR. Then all the gathered data was analysed in order to identify the features and attributes of IMR sites that affect the inter-organizational trust among them. Finally a statistical model was created, it allowed to assess the trust level between any given IMR site.

The study presented in this paper was the second phase of the main study. It was also based on in-depth interviews among the same managers, who assessed the readiness of the individual sites to undertake specified forms of cooperation with other sites on the route. Additionally the expectations towards a network structure on IMR were assessed, as well as the position of each site in the previous structure and preferences towards cooperation partnership. This with the previously created tool for assessing trust enabled us to create a configuration of a trust based cooperation network. The scheme of the whole study is presented in Figure 2.

\section{RESEARCHSCHEME}

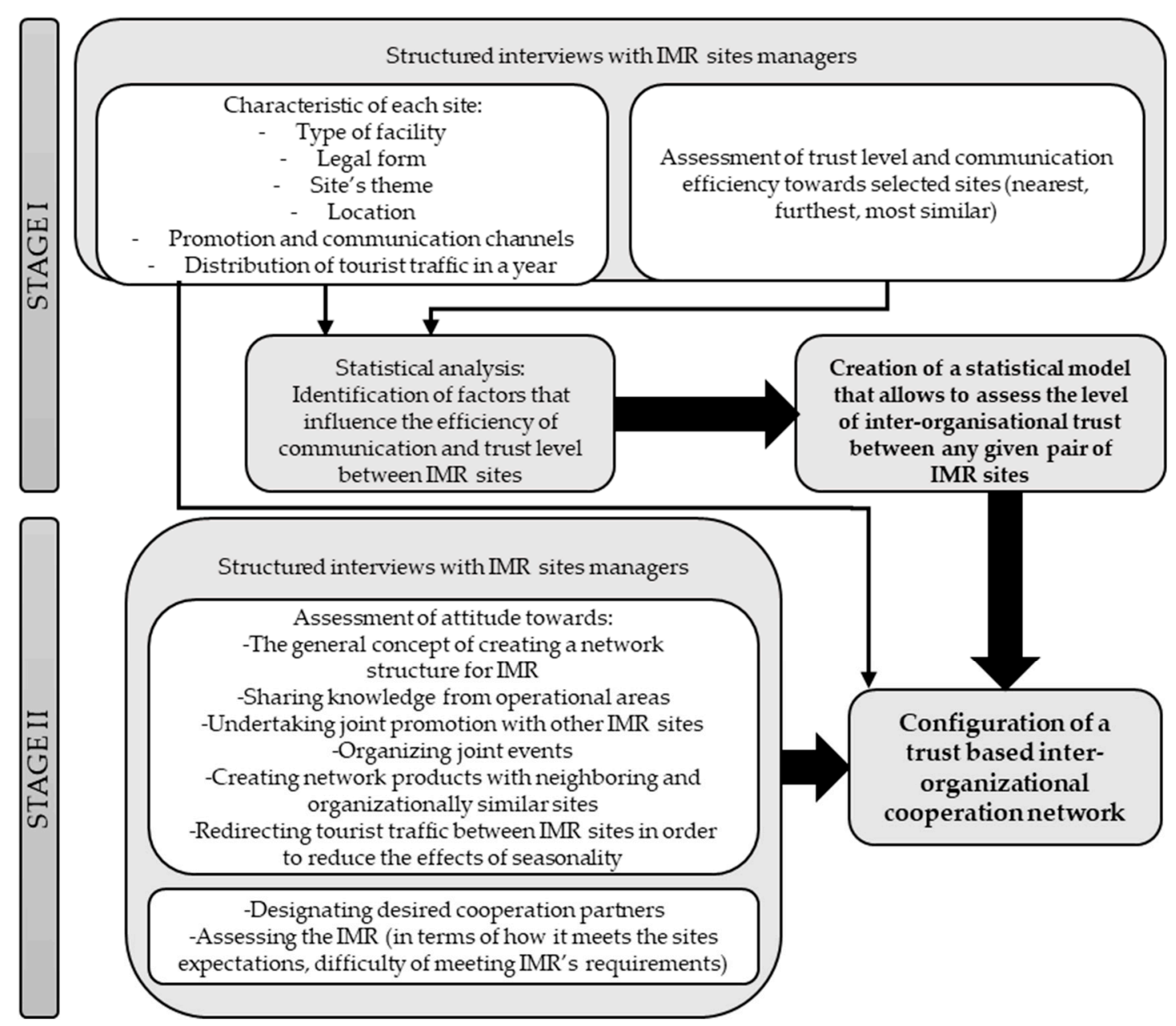

Figure 2. The two stage research scheme. Source: Authors own work.

The configuration includes only IMR sites, as it is meant to be used by the Marshals Office (it governs the route) to reorganize the IMR internal structure. Therefore the initial changes can be only applied directly to the members of the route. This is the reason, why the created configuration does 
not include external ventures that co-create the final tourist product of the route (hotels, restaurants, etc.). Even if the network configuration pertains only to the core of the route's product, future research could be focusing on extending this network model to include all environmental and external links between the IMR members and their partners and it should be the next step in network development.

\section{Results}

Previous studies [65] have confirmed that, among the identified factors influencing trust, there was geographical distance dividing the two sites, as well as features such as the level of readiness to undertake joint effort (creating a post for a person responsible for cooperation with other route sites and creating promotional materials for partners on own advertisement media). The most significant parameter, decisive for the level of inter-organizational trust, was the level of effectiveness of communication with the partners. Based on the obtained data, a statistical model was created, allowing to estimate the level of inter-organizational trust between any two IMR sites (expressed on a scale of 1 to 10 ).

During the described studies (also based on structured interviews by experts) that were conducted with senior managers and directors of all the IMR sites, the respondents were asked to state their expectations towards gains form introducing a network structure on IMR, but also towards threats they associate with this process, they were also asked about areas of cooperation on IMR that required to be improved in their opinion. As it goes to expected gains almost three fourths $(73.81 \%)$ of the interviewed experts expect that thanks to the networking they will gain new clients and better promotion. Other responds related to: improvement of cooperation (14.29\%), gaining founds $(11.90 \%)$, offer enrichment $(7.14 \%)$, preserving culture $(7.14 \%)$ and increased quality of service $(4.76 \%)$. The threats seen in networking IMR have been more diversified, fear of product cannibalization was the most frequent one $(19.05 \%)$, followed by excessive coopetition $(16.67 \%)$, operational cost increase $(11.90 \%)$, overwhelming work effort to sustain the network (7.14\%), division of sites into groups of privileged and unprivileged $(7.14 \%)$, and possible conflicts resulting from differences in opinions $(2.38 \%)$. The areas of cooperation within IMR requiring improvement according to the experts are: communication and experience sharing $(45.24 \%)$, joint promotion $(35.71 \%)$, creating joint products $(23.81 \%)$, reduction of thematic differences on the route $(7.14 \%)$ and gaining sponsorship $(2.38 \%)$. The intended network structure created in this study is meant to meet those statements. In order to reduce fear form the stated threats, trust was selected as the indicator for designating relations. Because the model used to assess inter-organizational trust between IMR sites strongly emphasises on communication efficiency the proposed network structure also answers the need for improved knowledge sharing and overall communication within IMR. The proposed configuration is also meant to take the other expectations and anxieties into consideration, by designating relations that correspond do them.

Further during the interviews the experts have been requested to assess the readiness of the represented site to undertake indicated forms of cooperation. This was made on a scale of 1 to 10 , where higher score stood for higher readiness. In the created network model, network relationships corresponding to a given form of cooperation were determined only when the two connected sites expressed the same view on the given form of cooperation, and if the degree of trust, defined previously using the described model, exceed a specific threshold. Since this was the first network model that could be implemented to the IMR, the authors created an upper quartile of the variable describing the degree of trust among all route sites as a threshold for creating network relations. The purpose was to ensure durability of the first relations in the emerging network, which, in the subsequent period, could lay foundations for its future development.

The first phase of designing inter-organizational network for IMR sites was to develop the most significant network roles among its participants, i.e., the network architect, brokers and mediators. In case of IMR, the role of an architect is assumed by the Marshal's Office, due to the fact that this is the authority that established the route and has coordinated it so far, and that many of the route's sites are 
dependent on co-financing from the office. The office thus constitutes, in a way, a central point for the presented model, binding together other nodes from the network center (brokers and mediators).

During the interviews conducted with representatives of the IMR sites, characterization of each of the sites was made (including in terms of: the number of tourists visiting the site throughout the year, attitude towards the networking process, impact of each site on the process of development of the route and the self-assessed strength of the position the site has in the route structure). In the created model of the network, units satisfying several criteria were selected for the role of brokers. The first candidates for the role of a broker for the network were sites known under their marketing phrase "Stars of Industry". These are the first four most developed sites with the largest number of visitors, which causes that they form, in a way, an image of the route as a whole in the minds of the clients ("Guido" Coal Mine - almost 100,000 visitors a year, The Historic Brewery in Żywiec - 83,000 visitors, The Museum of the Duke's Brewery - 70,000 visitors, and The Historic Silver Mine - 63,000 visitors). Apart from the mentioned sites, three other units were considered as candidates for the role of network mediators due to a large number of tourists served during a year, as well as high self-assessments in other considered aspects (Black Trout Adit - 40,000 visitors, Tradition Park - 49,000 visitors, and the "President" Shaft - 70,000 visitors).

During the final selection of the entities which were assigned the role of brokers in the model, two premises were taken into account. The first of them assumed that the estimated degree of trust should be as high as possible. If the highest assessment of the estimated trust occurred with the broker for which, in the conducted interview, the given entity expressed unwillingness to cooperate, a broker with the next higher level of estimated trust was selected. The other premise assumed that, to the furthest extent possible, connections should be established between sites with the same formal-law status. The reason was the intention of preventing difficulties in cooperation of sites with different ownership forms, as well as assuring high level of understanding of the method of operation by the broker. However, the prioritized criterion was the level of inter-organizational trust.

The result of the presented approach was the selection of five brokers in the created network model. Two private sites (The Museum of Duke's Brewery and The Historic Brewery in Żywiec), two public entities ("Guido" Coal Mine and the Tradition Park) and one site of the third sector ("President" Shaft). The map of relations of IMR sites with brokers in the proposed network is presented in Figure 3.

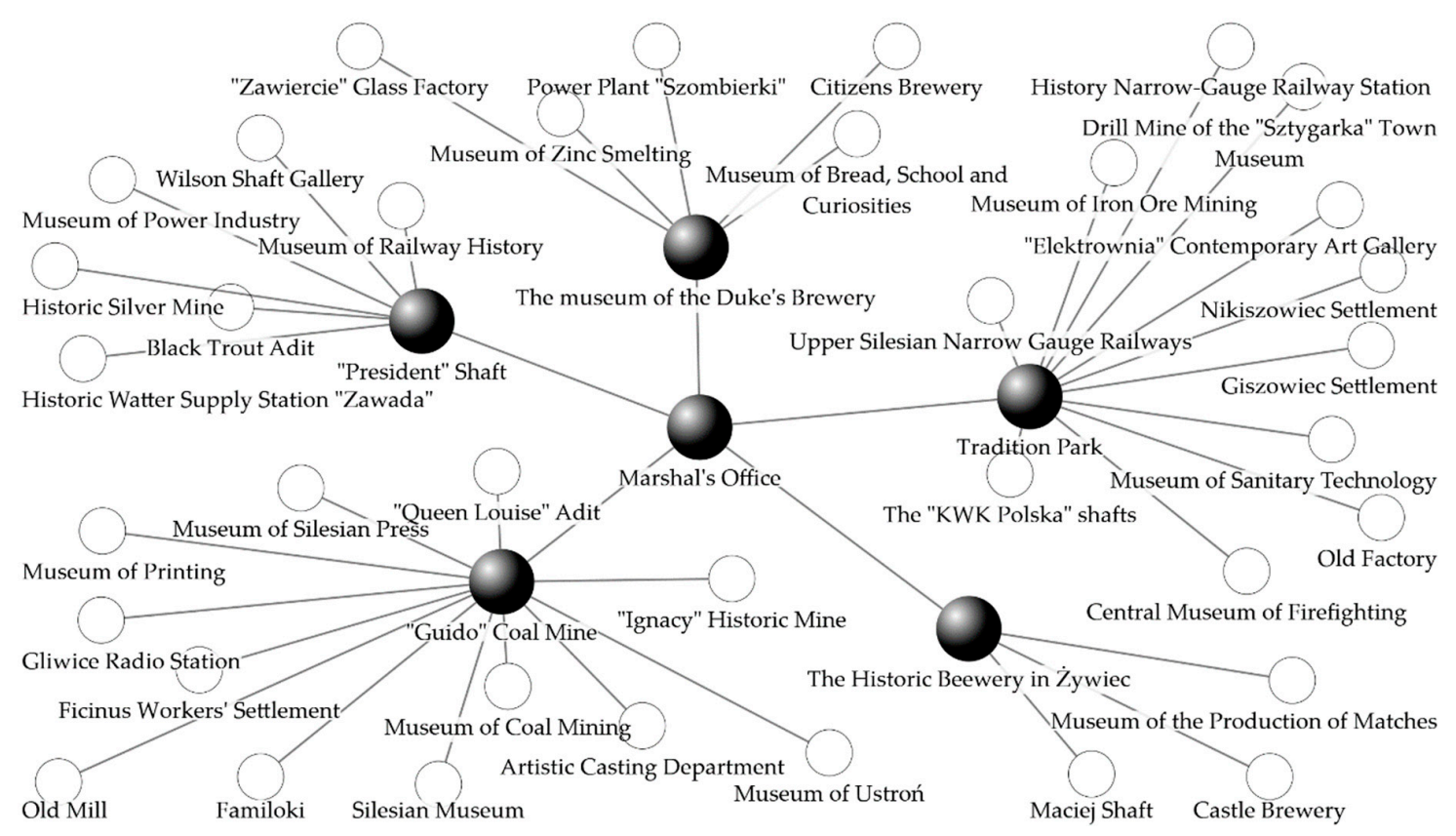

Figure 3. Network relations map between IMR facilities and proposed brokers. Source: Authors' own work. 
The next step in the configuration of the network was assigning its mediators, i.e., actors enjoying the largest trust of the remaining network participants, whose role is resolving conflicts. The role of mediators of the network was assigned to sites, towards which the largest possible number of other network participants expressed a high degree of trust (above the upper quartile of the variable describing that feature). In this way, the following were selected as mediators: Museum of Coal Mining (for 28 units, the calculated degree of trust towards the institution exceeded the value of the upper quartile), "President" Shaft (21), Upper Silesian Narrow Gauge Railways (20), Tradition Park (19), Castle Brewery (19) and the Nikiszowiec Settlement (17). Similar to defining network brokers, the sites were connected with a relation with the mediator with the highest degree of estimated trust of a given unit towards him.

The applied approach enabled to assign each of the assigned mediators to sites, which - according to the adopted model - have the largest degree of trust towards them. The most relations were established with Museum of Coal Mining (13) and the Upper Silesian Narrow Gauge Railways (6). In the remaining sites, the largest degree of trust occurred towards Nikiszowiec Settlement (7), Castle Brewery (5), Tradition Park (4) and "President" Shaft (2). The mediators were also connected with each other through network nodes, based on mutual trust, to resolve conflicts that directly concern them. The map of proposed relations with mediators of the inter-organizational network for IMR is presented in Figure 4.

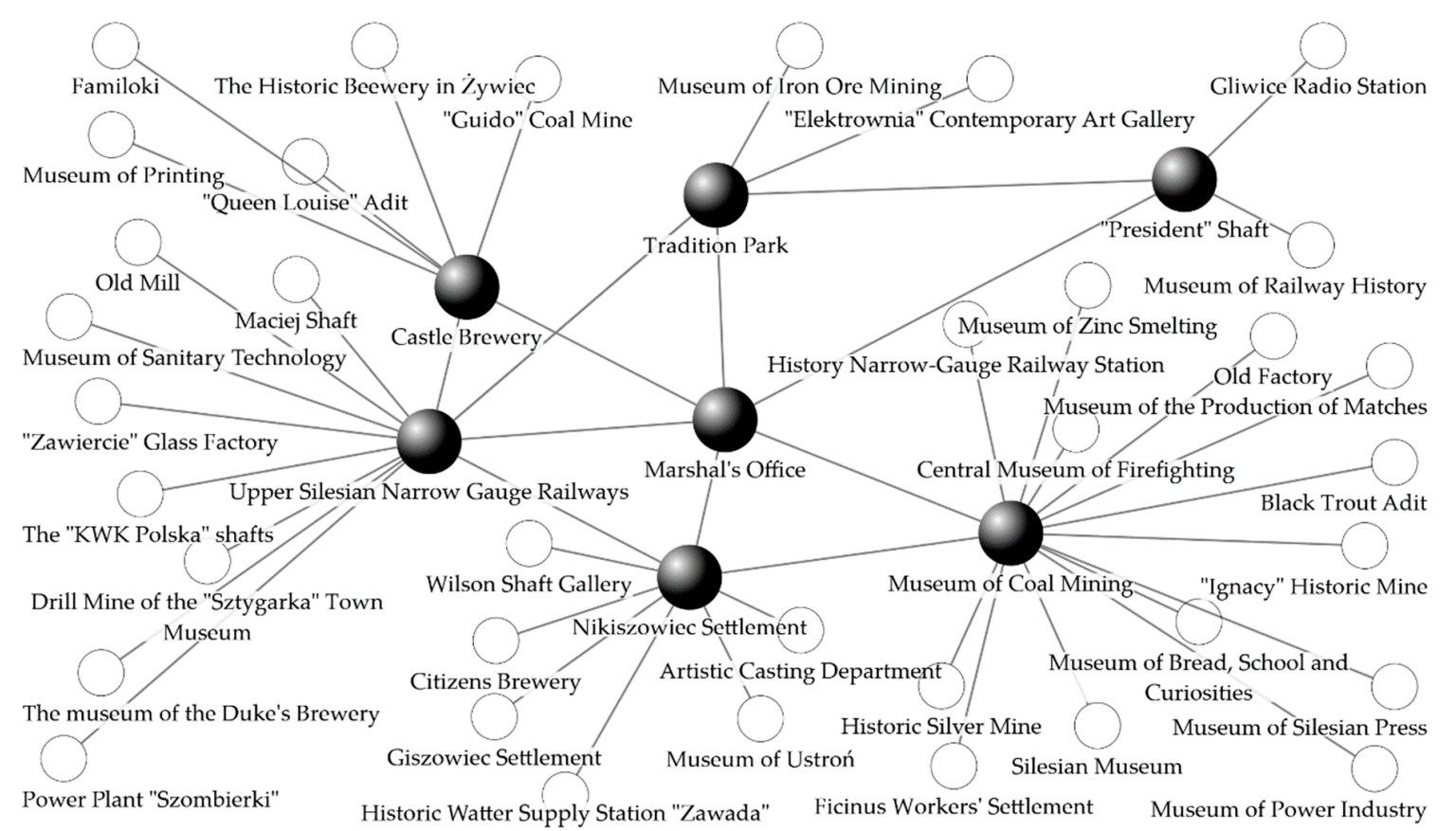

Figure 4. Network relations map between IMR facilities and proposed mediators. Source: Authors' own work.

The presented maps describe the relations enabling to coordinate the network. These are, however, vertical connections, not joining individual sites with each other. Another step in configuring the network was to determine connections of that kind. As a result of the conducted expert interviews, and basing on the analysis of IMR internal documentation made available to the authors by Marshal's Office, a number of areas were identified, potentially constituting the basis of inter-organizational relations in the presented network model. In the conducted studies, experts representing the sites of post-industrial tourism were requested to indicate units which they perceive as desirable partners for cooperation. Based on the obtained answers, a list of all proposed solutions was created (226). Among all the proposals, in 47 cases the estimated degree of trust exceeded the previously assumed criterion of the upper quartile. The map of relations meeting this criterion is presented in Figure 5. 
The units most often indicated as potential partners, and hence those towards which the estimated degree of trust exceeded the minimum threshold, were Museum of Coal Mining and "President" Shaft. Five connections with each of them were determined in the created network model.

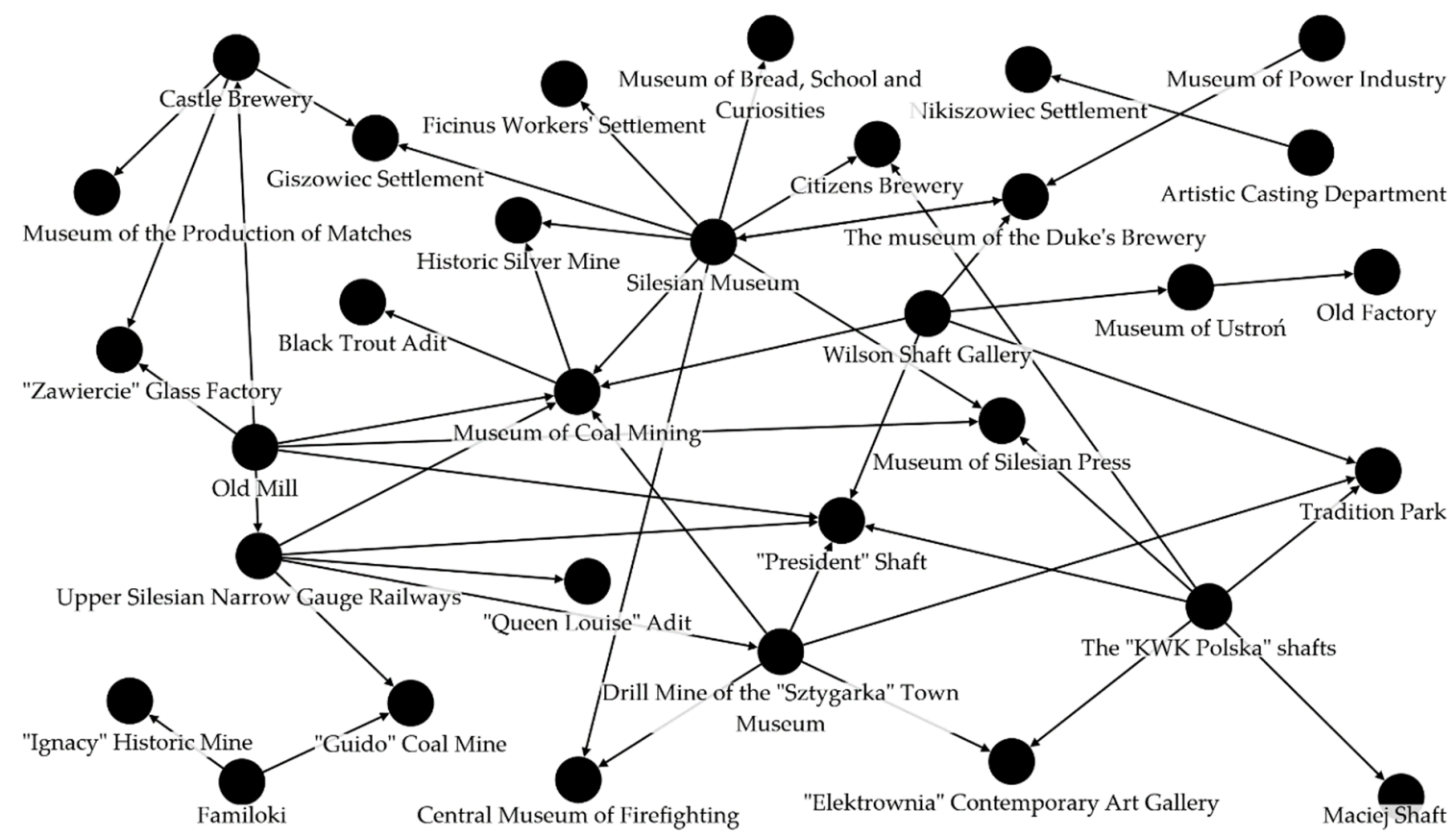

Figure 5. Relation map between network participants that pointed other facilities as a desired cooperation partner. Source: Authors' own work.

During the expert interviews, respondents were inquired about their readiness to exchange experiences in the selected scopes (organization of work in the site, system of bookings, promotional activity, obtaining funds, handling tenders, investment activities and sales). In this area, experts noted that the exchange of experiences is an activity that is necessary and required for further development of the route. Therefore, in the proposed network configuration, network relations connecting the sites were created, for which the degree of readiness to share knowledge and experiences on selected subjects was assessed in the same way. Figure 6 presents the map of these relations. It must be stressed here, that each of the indicated connections covered a different scope of exchange of experiences for each pair of sites. Only four relations concerned the exchange of experiences in all the mentioned scopes (between Castle Brewery and Ficinus Workers Settlement, the "KWK Polska" Shafts, the Museum of the Production of Matches and Drill Mine of the "Sztygarka" Town Museum. The other relations concerned the scopes of exchange of experiences in the selected pair of sites.

In the configured network, relations corresponding to joint promotional efforts were also determined. The connections were defined similarly to those that concerned sharing experiences. The experts representing the post-industrial tourist sites assessed their willingness to post promotional materials of the potential partners in the selected media (printed materials, website of the site, social media, site tickets, guide narratives). If, in the case of the two sites, the given information channel was assessed in the same way, and the estimated degree of inter-organizational trust satisfied the criterion of the upper quartile of that variable, network relation was determined in the described model. A graph illustrating the relations of the described scope is presented in Figure 7.

Other relations were also implemented into the inter-organizational network model for the IMR sites, applying similar criteria as in the previous cases. The first of the network connections remaining for determination was the willingness to undertake networking effort. Network relations were established between the sites that were equally ready for actions, such as: organization and participation in joint meetings devoted to the development of the IMR networking idea, establishing 
fixed electronic communication with network partners, creating a joint network cell with the partners and indicating delegates responsible for cooperation with the other members of the network. As a result, 80 bilateral connections were introduced into the network model.

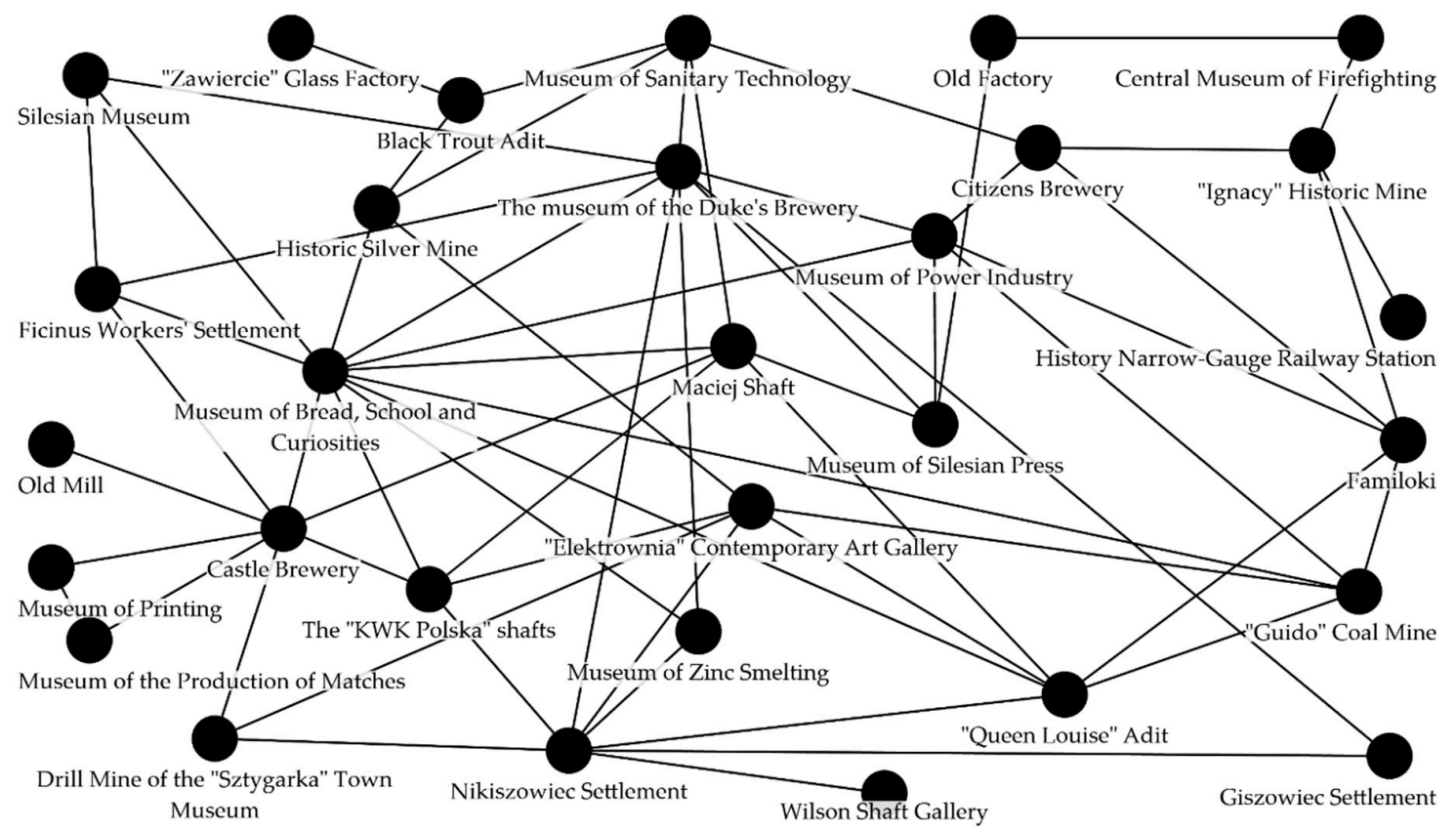

Figure 6. Relation map between network participants that were willing to share knowledge from similar operational areas. Source: Authors' own work.

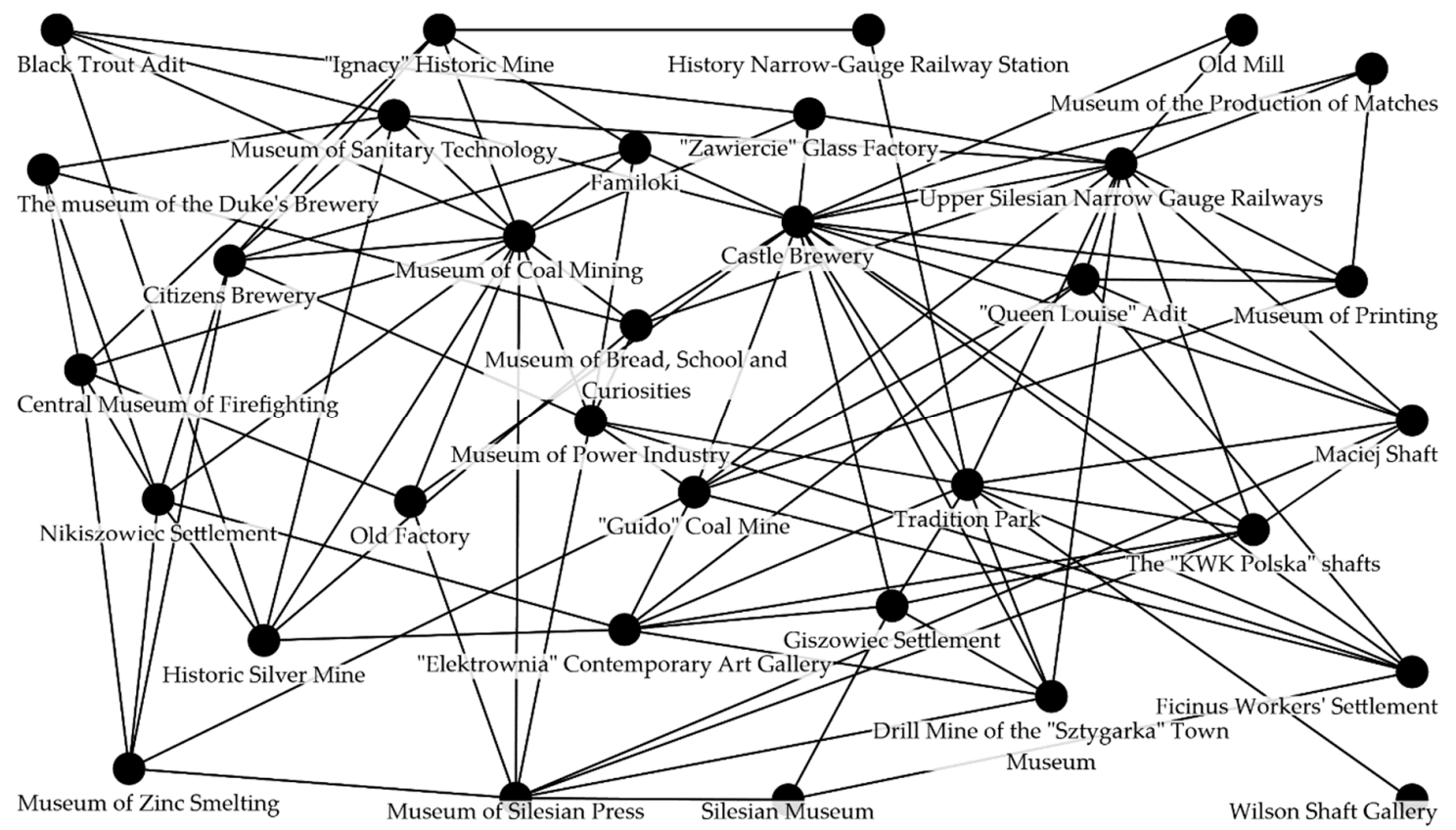

Figure 7. Relation map between network participants that were willing to undertake joint promotion.

Source: Authors' own work.

Another basis for establishing network relations was the willingness to create network products with other entities on the IMR, expressed by the respondents, which either feature high probability of the conducted activity or are located near each other. In this case, connections between the sites were introduced into the network model if the three following criteria were met: distance between the connected network actors was smaller than or equal to $13.2 \mathrm{~km}$ (lower quartile of the distances 
dividing the studied units), the estimated trust between the partners met the criterion of the upper quartile, the assessment of the attitude to creating network products with the neighboring entities obtained in the studies in the two sites exceeded 5 (a scale of 1-10 was used, where 5 stood for neutral attitude, and higher value expressed willingness to such effort). This way, 34 network relations were determined. Moreover, 26 network relations between sites with large institutional similarity (15 relations connecting museums, 8 connections between sites with a common theme that is transport in mining, and 3 relations pairing two mines, two settlements and two breweries).

Relations, the purpose of which was to reduce the negative effects of seasonability in certain IMR sites, were also included in the network model created by the authors. During the conducted expert interviews, varieties in the size of tourist traffic throughout the year at each of the studied entities were identified. It was observed that, for certain IMR sites, the peak of intensity in tourist traffic falls for the same period as the lowest visitor rates in the other sites, and vice versa. If, between the pair of such sites, the criterion of adequate degree of trust was satisfied, the relation which corresponded to the proposition of bilateral exchange of tourist traffic in the respective periods was included (by recommending the partner site, undertaking joint promotion etc.). 15 pairs of sites were designated this way.

The last platform used for introducing relations between post-industrial tourist sites in the created configuration of the inter-organizational network were the proposals for creating complementary products. The first group of this kind could be cyclic events, named "mini-Industriades" for the purpose of the described model. The name refers to the annual event organized at IMR, the so-called "Industriade", during which, for one day, all sites offer visitors unique attractions that relate to the theme set for a given year. In the majority of the sites, a promotional price list applies or entry is free of cost. The proposed additional events would concern individual six groups of sites on the route (museums, breweries, industrial monuments, workers' settlements, mines and other unique sites). The proposed solution would consist in organizing an event similar to the "Industriade" by the given group. Since six groups were identified, each of the "mini-Industriades" could take place every two months, each time in a different group of sites. The recommendation for creating such product was expressed in the audits conducted at IMR, the contents of which were made available to the authors of this paper. When determining network relations between the sites that could organize the mentioned events, 62 relations were created in the model ( 2 for breweries, 2 for mines, 16 for industrial monuments, 32 for museums and 10 for other unique sites). In the prepared network model for the IMR, another group of complementary products was also determined, which could be named the thematic routes. In this case, the focus was not on the kind of connected sites, but the heritage (former function) of the site. By using this criterion, managers of the route were proposed three different paths for connecting the industrial monuments. The first proposed path connects 13 sites using 12 relations, setting the route that shows the path of hard coal, from production in the mine, through means of transport, all the way to the production plant which used the raw material. The second of the proposed paths concerned 7 sites connected by 5 relations, and its theme was the achievements of the old technology (connecting sites related with press, communication and production of consumer goods from the times of industrialization). The last of the proposed thematic paths focused on the lives of the workers in the 19th and the early 20th century. Using 15 network relations, 12 tourist sites were determined, indicating several possible routes presenting workers' settlements, facilities producing food products (breweries, bread center, water treatment plant) and the culture of the region.

As a result of the previously presented connections between the post-industrial tourist sites, a complex configuration of the inter-organizational network was created with the use of horizontal relations. When perceiving the created inter-organizational network configuration holistically, one may conclude that it comprises 43 nodes (42 post-industrial tourist sites and the Marshal's Office). A total of 926 relations were created between the post-industrial tourist sites, 42 of which are unique and do not have a double in any field, and the other 884 concern more than one task (e.g., counteracting the 
phenomenon of seasonality and creating a network product). The definite advantage (95.68\%) of the formed relations concerns more than one scope.

For the needs of the created network configuration, the doubling connections were transformed into a single non-directional configuration, as presented in Figure 8 (i.e., cooperation of two sites on many levels was presented with a single connection). In this case, 236 nodes may be indicated, with each of them being unique and applying to different spheres of cooperation. The exact measures describing the created inter-organizational network for post-industrial tourist sites are presented in Table 1.

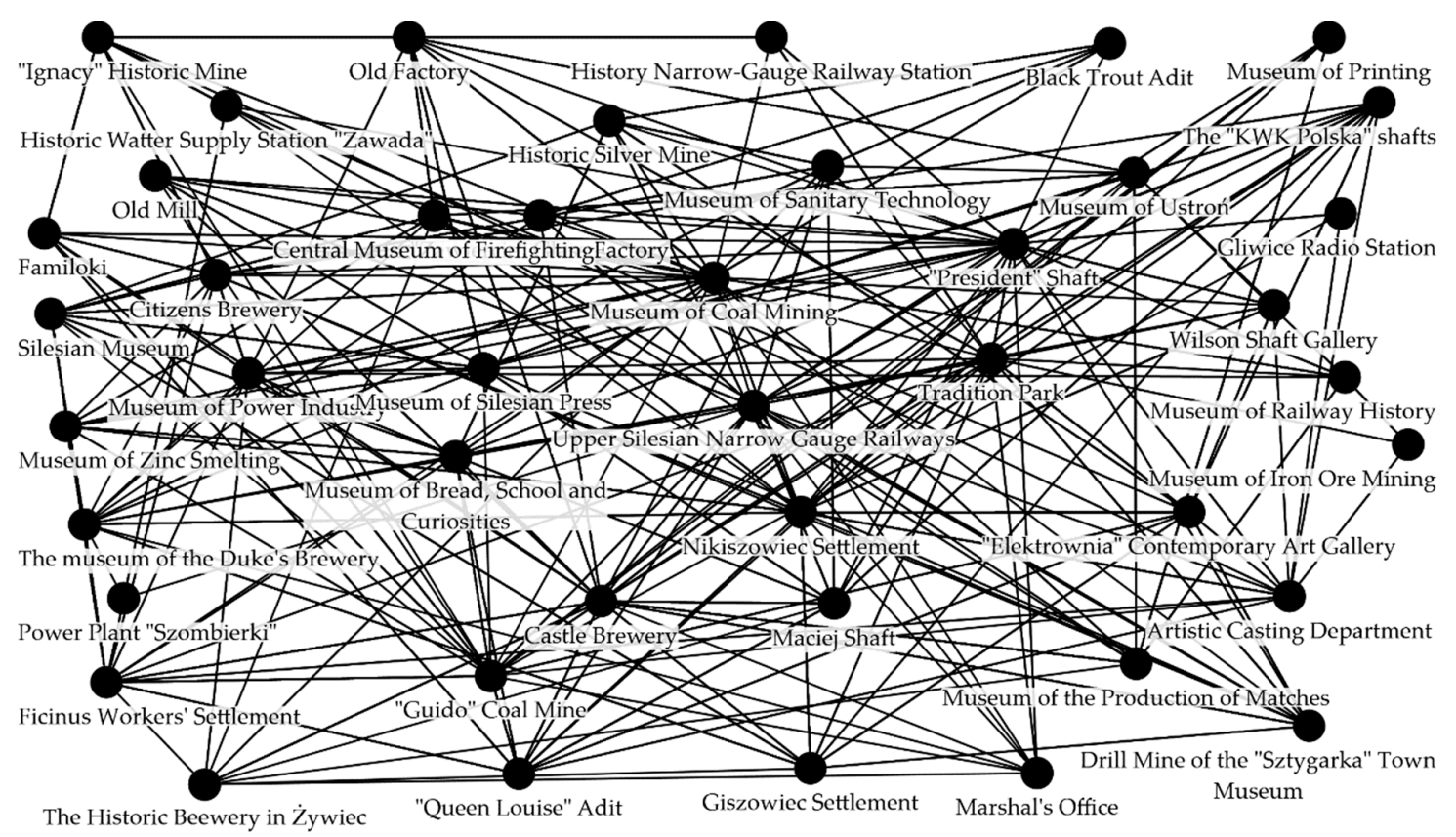

Figure 8. Relation map of the whole cooperation network for IMR sites in all aspects. Source: Authors' own work.

Table 1. Parameters of the configured network.

\begin{tabular}{|c|c|c|}
\hline Parameter & Value & Formula/Description \\
\hline Numerical amount $\mathrm{N}$ & 43 & The network's size: number of vertices/players. \\
\hline $\mathrm{E}$ & 236 & Number of edges (without repetitions) \\
\hline Network density - D & $26.15 \%$ & $D=\frac{2 E}{N(N-1)}$ \\
\hline The average degree of vertices $<k>$ & 10.98 & $\begin{array}{l}\text { The degree of a vertex }(\mathrm{k}) \text { is the number of edges going in and out of it, } \\
\qquad k>\text { is the average value for all vertices. }\end{array}$ \\
\hline The average path length & 1.75 & The average value from the shortest paths between all vertices. \\
\hline Network diameter & 3 & $\begin{array}{l}\text { The longest path between two vertices selected from the set of the } \\
\text { shortest possible paths between any two given vertices. }\end{array}$ \\
\hline Vertices asymmetry & 0.832 & The degree of asymmetry of the vertices \\
\hline Network heterogeneity coefficient & 0.109 & $p(G)=\frac{\sum_{i, j \in E}\left(k_{i}^{-\frac{1}{2}}-k_{j}^{-\frac{1}{2}}\right)}{n-2 \sqrt{n-1}}$ \\
\hline Clustering coefficient & 0.41 & $\begin{array}{l}\qquad C=\frac{\sum_{i=1}^{N} C_{i}}{N} ; C_{i}=\frac{2 e_{i}}{k_{i}\left(k_{i}-1\right)} \\
\text { Where } k_{i} \text { is the number of vertices connected with the } i \text {-th vertex, and } e_{i} \\
\text { is the number of edges connecting those vertices. (This coefficient } \\
\text { shows the degree to which the neighboring vertices are related.) }\end{array}$ \\
\hline
\end{tabular}

The coefficient of density of the created network is $26.13 \%$, which means that the proposed configuration is implemented by a little over one fourth of all the potentially possible connections. The majority of sites is closely related to each other (the average length of the path between the pair 
of sites is 1.79), and the average network is 3 . This means that the majority of sites does not require many mediators to reach a unit with which it has no direct connection. Site pairs that have direct contact account for $27.06 \%$ of the whole network; in $67.25 \%$ of cases only one mediator is necessary, and the other $5.69 \%$ of site pairs require two links in the network to have contact with each other. High degree of asymmetry of the peak levels indicates the right-hand distribution of that variable - there are numerous high level peaks, increasing the value of the arithmetic mean.

The cluster coefficient at the level of 0.4071 allows to conclude that, on average, the number of connections between all the neighbors of a given node accounts for around $41 \%$ of the maximum possible number. The presented heterogeneity level of the network allows to compare it with other inter-organizational networks.

\section{Conclusions and Discussion}

The main goal of the study was to develop and apply a method of designing a network structure for tourist sites that form a tourist route, that haven't been part of a network before-hence, the configuration is a network initiation, on which later relations can be built upon. Such approach can be applied within centrally controlled route in order to change a top to bottom hierarchy in favour of more horizontal relations. Our finding from literature review suggest that this is necessary in modern tourism, in order for the facilities to stay competitive, but also to preserve heritage they present and maintain. Other expected gains are growth in organisational learning and knowledge sharing, consequently leading to competitive advantage through cost reduction and value creation for clients.

Unlike in existing networks where one can use indicators from previous cooperation activity, in case of a network initiation different indicators have to be used in order to designate network relations. Or claim is, that this can be done with the help of inter-organizational trust level indicators. The literature review findings support this approach. It was shown that trust is a key factor in maintain a proper balance between cooperation and competition within a network (one must mention here, that trust can also be abused, and this should be taken into account when calculating the risks involved within a network). Trust is also a necessary condition for cooperation to grow, it stimulates communication and knowledge sharing, as well as allows to overcome the anxieties associated with entering new structures. Trust was also chosen as an indicator for designating network relations because it could be measured between tourist sites on the same route, even if there was no network structure before. The literature review revealed also, that even if the network approach is known and appreciated in tourism, there was never an attempt to actually configure an inter-organizational network for tourist sites on a route. The previous research focused either on analysing already existing networks or on discovering the network paradigm in different areas of tourism, like i.e., hospitality or gastronomy. Our work contributes to reducing the gap concerning initial network design within tourist routes.

Planning and configuration of an inter-organizational network for post-industrial tourist sites was and still remains a complex task. On the one hand, large heterogeneity of sites on the post-industrial routes may facilitate the configuring of a network and foster the process of implementing the network, stimulating its development at the later stage. However, on the other hand, thematic tourist routes are a special kind of routes. They have many characteristic features, which cause that the management of this sort of sites significantly differs from the management of other enterprises operating in the tourist industry, preventing the direct translation of the business solution to management of the route. The same also applies for networking.

The model of an inter-organizational network, created by the authors and presented in the paper, was created for post-industrial tourist sites belonging to the IMR. The research showed that one of the most significant expectation from a network on a route, in the opinion of managers of the IMR tourist sites, was gaining new clients and more effective mutual promotion. The threats and anxieties associated with entering network structure were more diversified, among them the experts expressed concerns about product cannibalization and excessive coopetition. Therefore this was another reason 
to use trust as an indicator for designating relations within this network - in order to reduce the risk of those feared outcomes taking place. The degree of trust between the post-industrial tourist sites was estimated by using a statistical model developed by the authors in their previous research $[65,69]$. In the configured network connections have been designated only between those sites, for which the estimated trust level fell within the upper quartile of that variable. The designated network relations concerned various forms of cooperation available for post-industrial tourism establishments, identified during a critical analysis of the subject literature and expert interviews conducted with managers of post-industrial tourist sites. The forms of cooperation, for which network relations were created in the presented network configuration include:

- creating network products based on the theme of the products of individual sites (setting thematic paths and the so-called "mini-Industriades"),

- creating network products between geographically close sites,

- exchange of experiences and knowledge in the selected spheres of knowledge, as well as sustainable development practices, with respect to protecting the post-industrial heritage and preserving it for future generations,

- conducting joint promotional effort in selected areas of activity,

- counteracting the effects of seasonality,

- counteracting the loss of cultural and regional identity of the local community, whom the presented heritage concerns.

A step necessary to improve the functioning of the configured network was to appoint sites acting as brokers and mediators of the network. Since the task of network mediators is resolving conflicts occurring within the network, this role was assigned to those sites, the trust towards which on the part of the majority of the studied units satisfied the assumed criteria. The task of brokers, on the other hand, is to coordinate network activities. This role was assigned within the created network to those sites, that were characterized by both large degree of trust on the part of the other members of the network, as well as long period of operation (experience, seniority), communication capabilities and their impact on IMR.

To conclude, it may be stated that inter-organizational networks are a form of cooperation that can be applied to the unique branch of the economy that is tourism and specifically to tourist routes and heritage tourist sites. Conducted research and the created network configuration lay grounds for implementing the described model to the structure of the post-industrial tourist sites, which were previously associated under a centrally controlled tourist route. Large heterogeneity of the assessed sites was not an obstacle to the creation of a network configuration, and sometimes facilitated creating additional and unique network relations, aiming at balancing the development of the conducted activity in order to preserve the cultural heritage.

The performed process of inter-organizational network configuration is not a universal recipe for creating networks in any given tourist route. It was created with sites lying on the IMR in mind, but may create a pattern when undertaking efforts for performing a similar task on other tourist routes as well. Another limitation was that the created model was designed with the intention of changing a hierarchal structure to a network one, this brings two additional limitations up. The first one is that the network structure concerns IMR sites only, without portraying connections to the environment and external stakeholders who create the final tourist product of the route. The second one is that because there was no indication of horizontal cooperation before within IMR the all the connections have been designated basing on assessments of trust level as a potential indicator of successful partnership. This method has proven itself useful in our case of a route where the network is being designed from the ground, but in case of an already functioning network other indicators might be more precise and adequate. Further studies and attempts to create inter-organizational networks for tourist routes may provide necessary observations for developing a universal methodology of creating networks for this kind of groups of tourist entities. Moreover further studies could be dedicated to expanding the 
created methodology and network model so it includes all stakeholders of the IMR. When time passes the case of IMR network should be revisited in order compare it's actual structure to the one presented herein, as well as to compare it to other routes that adapted the network structure, and to analyse it in the scope of social networks. Lastly, future studies could be dedicated to comparing other cooperation potential indicators that can be used to construct a network to the trust approach.

Author Contributions: M.N. reviewed the literature in terms of business models and post-industrial enterprises, conducted a research as well as prepared the characteristics of the Industrial Monuments Route in Poland. A.R.S. developed the methodology, introduction and conclusions, research, as well prepared the final contents of the article and proofread and revised it.

Funding: This research received funding by the National Science Center in Poland.

Acknowledgments: This paper was published as part of the research project 'A business model for health resort enterprises' No. 2017/25/B/HS4/00301, supervised and financed by the National Science Center in Poland and as part of statutory research 13/010/BK_19/0034 - PROWIZORIUM at the Silesian University of Technology, Faculty of Organization and Management.

Conflicts of Interest: The authors declare no conflict of interest. The funders had no role in the design of the study; in the collection, analyses, or interpretation of data; in the writing of the manuscript, or in the decision to publish the results.

\section{References}

1. Rapacz, A.; Jermen, D.E.; Gryszel, P. Dolina pałaców I ogrodów jako przejaw współpracy na rynku turystycznym. Acta Sci. Pol. Oeconomia 2010, 9, 413-421.

2. Czernek, K.; Żemła, M. Podejście sieciowe w turystyce-Charakterystyka i sposoby zastosowania. Folia Tur. 2016, 41, 237-260.

3. Edelendos, J.; Klijn, E.H. Trust in complex decision-making networks: A theoretical and empirical explanation. Adm. Soc. 2007, 39, 25-50. [CrossRef]

4. Fukuyama, F. Trust: The Social Virtues and the Creation of Prosperity; Penguin Putnam: New York, NY, USA, 1995.

5. Growiec, K.; Growiec, J. Social capital, trust, and multiple equilibria in economic performance. Macroecon. Dyn. 2014, 18, 282-315. [CrossRef]

6. Bottero, M.; D'Alpaos, C.; Oppio, A. Ranking of adaptive reuse strategies for abandoned industrial heritage in vulnerable contexts: A multiple criteria decision aiding approach. Sustainability 2019, 11, 785. [CrossRef]

7. Kuščer, K.; Mihalič, T. Residents' attitudes towards overtourism from the perspective of tourism impacts and cooperation-The case of ljubljana. Sustainability 2019, 11, 1823. [CrossRef]

8. Chenxi, L.; Zhengyan, C.; Jing, C.; Ning, Z. Brand revitalization of heritage enterprises for cultural sustainability in the digital era: A case study in China. Sustainability 2019, 11, 1769.

9. Wang, R.; Liu, G.; Zhou, J.; Wang, J. Identyfying the critical stakeholders for the sustainable development of architectural heritage of tourism: From the perspective of China. Sustainability 2019, 11, 1671. [CrossRef]

10. Pop, I.L.; Borza, A.; Buiga, A.; Ighian, D.; Toader, R. Achieving cultural sustainability in museums: A step toward sustainable development. Sustainability 2019, 11, 970. [CrossRef]

11. Weng, L.; He, B.; Liu, L.; Li, C.; Zhang, X. Sustainability assessment of cultural heritage tourism: Case study of pingyao ancient city in China. Sustainability 2019, 11, 1392. [CrossRef]

12. Nuhoff-Isakhanyan, G.; Wubben, E.F.M.; Omta, S.W.F. Sustainability benefits and challenges of inter-organisational collaboration in bio-based business: A systematic literature review. Sustainability 2016, 8, 307. [CrossRef]

13. Kożuch, B.; Sienkiewicz-Małyjurek, K. Inter-organisational coordination for sustainable local governance: Public safety management in Poland. Sustainability 2016, 8, 123. [CrossRef]

14. Ofoegbu, C.; New, G.M.; Staline, K. The effect of inter-organisational collaboration networks on climate knowledge flows and communication to pastoralists in Kenya. Sustainability 2018, 10, 4180. [CrossRef]

15. Shi, X.; Jing, R.; Hou, G.; Wang, J. Network position advantage and technological innovation of China's new energy vehicle based on the perspective of network theory. Sustainability 2019, 11, 2098. [CrossRef]

16. Hall, C.M. Rethinking collaboration and partnership: A public policy perspective. J. Sustain. Tour. 1999, 7, 274-289. [CrossRef] 
17. Hall, C.M.; Page, S.J. Progress in tourism management: From the geography of tourism to geographies of tourism-A review. Tour. Manag. 2009, 30,3-16. [CrossRef]

18. Stabryłwa, A.; Wawak, S. Metody Badania i Modele Rozwoju Organizacji, Encyklopedia Zarzadzania; Mfiles.pl: Kraków, Poland, 2012.

19. Gomes-Cassers, B. Group versus group: How alliance networks compete. Harv. Bus. Rev. 1994, 72, $62-66$.

20. Mikuła, B.; Pietruszka-Ortyl, A. Organizacje sieciowe. Zeszyty Naukowe Akademii Ekonomicznej w Krakowie 2006, 715, 113-130.

21. Kale, P.; Dyer, J.H.; Singh, H. Alliance capability, stock market response and long-term alliance success: The role of the alliance function. Strateg. Manag. J. 2002, 23, 747-767. [CrossRef]

22. Klimas, P. Uwarunkowania skutecznej współpracy międzyorganizacyjnej. Studia Ekon. 2013, 141, $185-198$.

23. Gulati, R. Alliances and networks. Strateg. Manag. J. 1998, 19, 293-317. [CrossRef]

24. Czakon, W. Sieci międzyorganizacyjne a niepewność w zarządzaniu przedsiębiorstwem. In Zmiany w Systemach Zarzadzania Polskich Przedsiębiorstw; Kozakiewicz, K., Ed.; Wydawnictwo AE: Poznań, Poland, 2007.

25. Thompson, G. Between Hierarchies and Markets: The Logic and Limits of Network Forms of Organization; Oxford University Press: Oxford, UK, 2003.

26. Otte, E.; Rousseau, R. Social network analysis: A powerful strategy, also for the information sciences. J. Inf. Sci. 2002, 28, 441-453. [CrossRef]

27. Huang, C.; Chen, T.; Yi, H.; Xu, X.; Chen, S.; Chen, W. Collaborative enviromental governance, inter-agency cooperation and local water sustainability in China. Sustainability 2017, 9, 2305. [CrossRef]

28. Moggi, S.; Bonomi, S.; Ricciardi, F. Against food waste: CSR for the social and environmental impact through a network-based organizational model. Sustainability 2018, 10, 3515. [CrossRef]

29. Delporte-Vermeiren, D.; Vervest, P.; Van Heck, E. In search of margin for business networks: The european patent office. Eur. Manag. J. 2004, 22, 167-182. [CrossRef]

30. Mu, R.; Jia, J.; Leng, W.; Haershan, M.; Jin, J. What conditions, in combination, drive inter-organizational activities? Evidence from cooperation on environmental governance in nine urban agglomerations in China. Sustainability 2018, 10, 2387. [CrossRef]

31. Sørensen, E.; Torfing, J. Theories of Democratic Network Governance; Palgrave Macmillan: Basingstoke, UK, 2007.

32. Provan, K.G.; Kenis, P. Modes of network governance: Structure, management, and effectiveness. J. Public Adm. Res. Theory 2008, 18, 229-252. [CrossRef]

33. Austen, A. In search of network sustainability: A multi-level perspective on the paradox of cooperation and competition in networks. Sustainability 2018, 10, 2466. [CrossRef]

34. Lee, I.; Feiock, R.C.; Lee, Y. Competitors and cooperators: A micro-level analysis of regional economic development cooperation networks. Public Adm. Rev. 2012, 72, 253-262. [CrossRef]

35. Provan, K.; Lemaire, R.H. Core concepts and key ideas for understanding public sector organizationalnetworks: Using research to inform scholarship and practice. Public Adm. Rev. 2012, 72, 638-648. [CrossRef]

36. Börjeson, L. Trust and betrayal in interorganizational relationships: A systemic functional grammar analysis. Hum. Relat. 2018, 71, 399-426. [CrossRef]

37. Newell, S.; Swan, J. Trust and inter-organizational networking. Hum. Relat. 2000, 53, 1287-1327. [CrossRef]

38. Chen, B. Assessing interorganizational networks for public service delivery: A process-perceived effectiveness framework. Public Perform. Manag. 2008, 31, 348-363.

39. Klijn, E.H.; Sierra, V.; Ysa, T.; Berman, E.; Edelenbos, J.; Chen, D.Y. The influence of trust on network performance in Taiwan, Spain, and the Netherlands: A cross-country comparison. Int. Public Manag. J. 2016, 19, 111-139. [CrossRef]

40. Oomsels, P.; Bouckaert, G. Studying interorganizational trust in public administration: A conceptual and analytical framework for "administrational trust". Public Perform. Manag. Rev. 2014, 37, 577-604. [CrossRef]

41. Powell, W.W.; Koput, K.W.; Smith-Doerr, L. Interorganizational collaboration and the locus of innovation: Networks of learning in biotechnology. Adm. Sci. Q. 1996, 41, 116-145. [CrossRef]

42. Niemczyk, J.; Stańczyk-Hugiet, E.; Jasiński, B. Sieci Międzyorganizacyjne, Współczesne Wyzwanie dla Teorii $i$ Praktyki Zarzadzania; C.H. Beck: Warszawa, Poland, 2012.

43. Jagoda, H.; Haus, B. Holding. Organizacja i Funkcjonowanie; PWE: Warszawa, Poland, 1995.

44. Van der Zee, E.; Vanneste, D. Toursim networsk unravelled; a review of the literature on networsk in tourism management studies. Toursim Manag. Perspect. 2015, 15, 46-56. [CrossRef] 
45. Wray, M. Policy communities, networks and issue cycles in tourism destination systems. J. Sustain. Tour. 2009, 17, 673-690. [CrossRef]

46. Halme, M. Learning for sustainable development in tourism networks. Bus. Strategy Environ. 2001, 10, 100-114. [CrossRef]

47. Sørensen, F. The geographies of social networks and innovation in tourism. Tour. Geogr. Int. J. Tour. Space Place Environ. 2007, 9, 22-48. [CrossRef]

48. Erkuş-Öztürk, H. The role of clusters types and firm sizes in designing level of network relations: The experience from the Antalya tourism region. Tour. Manag. 2009, 30, 589-597. [CrossRef]

49. Fuglsang, L.; Eide, D. The experience turn as 'bandwagon': Understanding network formation and innovation as practice. Eur. Urban Reg. Stud. 2013, 20,417-434. [CrossRef]

50. Van der Zee, E.; Go, F.M. Analysing beyond the environmental bubble dichotomy: How the 2010 World Cup case helped to bridge the host-guest gap. J. Sport Tour. 2013, 18, 161-183. [CrossRef]

51. Wäsche, H.; Dickson, G.; Woll, A. Quality in regional sports tourism: A network approach to strategic quality management. J. Sport Tour. 2013, 18, 81-97. [CrossRef]

52. Albrecht, J.N. Networking for sustainable tourism-Towards a research agenda. J. Sustain. Tour. 2013, 21, 639-657. [CrossRef]

53. Cawley, M.; Marsat, J.-B.; Gillmor, D.A. Promoting integrated rural tourism: Comparative perspectives on institutional networking in France and Ireland Tourism geographies. Int. J. Tour. Space Place Environ. 2007, 9, 405-420. [CrossRef]

54. Gretzel, U.; Fesenmaier, D.R. Implementing a knowledge-based tourism marketing information system. Ill. Tour. Netw. Inf. Technol. Tour. 2003, 6, 245-255. [CrossRef]

55. Novelli, M.; Schmitz, B.; Spencer, T. Networks, clusters and innovation in tourism: A UK experience. Tour. Manag. 2006, 27, 1141-1152. [CrossRef]

56. Pavlovich, K. The evolution and transformation of a tourism destination network: The Waitomo Caves, New Zealand. Tour. Manag. 2003, 24, 203-216. [CrossRef]

57. Scott, N.; Baggio, R.; Cooper, C. Network Analysis and Tourism: From Theory to Practice; Channel View Publications: Toronto, ON, Canada, 2008.

58. Dredge, D. Local tourism governance: A comparison of three network approaches. J. Sustain. Tour. 2010, 18, 7-28.

59. Bell, S. "Appropriate" policy knowledge, and institutional and governance implications. Aust. J. Public Adm. 2004, 63, 22-28. [CrossRef]

60. Halley, P. Transforming governance: Challenges of institutional adaptation and a new politics of space. Eur. Plan. J. 2006, 14, 299-320. [CrossRef]

61. White, L. Effective governance through complexity thinking and management science. Syst. Res. Behav. Sci. 2001, 18, 241-257. [CrossRef]

62. Dredge, D. Policy networks and the local organization of tourism. Tour. Manag. 2006, 27, 269-280. [CrossRef]

63. Kurkowska-Pysz, J.; Szczepańska-Woszczyna, K. The analysis of the determinants of sustainable cross-border cooperation and recommendations on its harmonization. Sustainability 2017, 9, 2226. [CrossRef]

64. Presenza, A.; Cipollina, M. Analysing tourism stakeholders network. Tour. Rev. 2010, 65, 17-30. [CrossRef]

65. Szromek, A.R.; Naramski, M. Measuring trust in business relations between tourist facilities on one thematic touristic route. Sustainability, revised version uder review;

66. Estrada, E. Quantifying network heterogeneity. Phys. Rev. 2010, 82, 066102. [CrossRef]

67. Czakon, W. Sieci w Zarzadzaniu Strategicznym; Wolters Kluwer: Waszawa, Poland, 2012.

68. NetworkAnalyzer Online Help. Available online: http://med.bioinf.mpi-inf.mpg.de/netanalyzer/help/2.7/ index.html\#complex (accessed on 9 April 2019).

69. Naramski, M.; Szromek, A.R. Model Sieci Wspótpracy Podmiotów Turystycznych; Wyd. Politechniki Śląskiej: Gliwice, Poland, 2018; p. 236.

(C) 2019 by the authors. Licensee MDPI, Basel, Switzerland. This article is an open access article distributed under the terms and conditions of the Creative Commons Attribution (CC BY) license (http://creativecommons.org/licenses/by/4.0/). 